\title{
Some Peculiarities of Russian Cultural Constants in the Language and Culture of Mongolia
}

\author{
Magsar Tseven \\ Mongolian State Pedagogical University, Ulan Bator, Mongolia \\ tsmagsar@mail.ru
}

\begin{abstract}
This article examines the issue of some peculiarities of Russian cultural constants that transferred into the language and culture of Mongolia in the twentieth century. The aim is to show the specificity of the existence of constant elements of Russian culture that are present in the Mongolian language and culture, which are actively used in the social and everyday sphere of communication nowadays.
\end{abstract}

Keywords: language, a cultural constant, specificity, concept, influence

\section{Introduction}

The presence of any elements of one national culture in the culture or language of another nation is a quite widespread phenomenon, especially in the modern era of globalization. But, in terms of significance of not only intercultural or interlingual communication, but perhaps even regarding the social and economic aspect, such elements can play a special role in the formation of a new cultural layer on the foundation of the national culture. If we consider the issue from the point of view of Russian culture, then it seems to the author that in the twentieth century there was a rapid process of transition of elements of Russian culture into the culture of the countries of Central Asia within the former Soviet Union, and beyond its borders into the culture of Mongolia, as there are numerous borrowings that entered the Mongolian language from Russian or through Russian. The most active period of this process took place from about the1930s up to the 1980s and historically it is associated with certain innovations or the development of a specific area of economy or culture in Mongolia.

In chronological terms, it is not difficult to establish exactly when and what kind of Russianisms entered the Mongolian lexicon, although most of them are not recorded anywhere in writing. In general, in the modern era the issue of borrowings spread in the language of a particular nation, 
in our opinion, belongs to a number of such research subjects that, in terms of the development of national languages are more labile and fluid which is sometimes associated with the level of interdependence and interaction of all languages and cultures. It is a natural process that in different periods of time elements of one culture dominate in relation to another, and as a result specific aftermaths of influence remain in the national language or, perhaps, even in the public consciousness. There was just such a period of active intercultural dialogue, which pushed the Russian and Mongolian languages towards "close communication". That was the twentieth century, the so-called period of socialism. Despite reformers' negative attitude towards it, this historical period for Mongolia was characterized by a rise in social and cultural development, the conquest of the country's full sovereignty. Moreover, in the conditions of wars, poverty and other social disasters, nations became closer to each other, many problems were solved free of charge. These conditions for sure contributed to the adoption of foreign language vocabulary or elements of culture different to the Mongolian one.

\section{Aim of research}

Based on such circumstances, in this article we aim to show some specific constant elements of Russian culture in the modern Mongolian language and culture, in addition to the fact that a lot of Russianisms are also used in the speech of the Mongols. This fact can prove the particular process of the influence of some cultural-national elements on others, especially through the interaction of unfamiliar languages, since the culture constants themselves are the core of the cultural picture of the world of a particular nation.

\section{Methodology perspective}

What perspective do we see the concept of a culture constant in? We agree with the opinion of the scholar Y.S. Stepanov that the basis of the notion "constant of culture" is "a concept (i.e., the basic units of the world picture framed by culture) that exist constantly or, at least, for a very long time" [https://myfilology.ru/149/kulturnye-konczepty-i-konstanty/]. As an essential feature, cultural constants contain the most characteristic features and phenomenal properties of national culture, give it different tones, and create a cultural frame. By the constant elements, we can easily distinguish, for example, eastern and western types of cultures. For Mongolian culture, the twentieth century was significant because it was greatly enriched with 
elements of Western culture in a relatively short period of time, first of all, directly through a contact with Russian culture, and as a result, modern Mongolian culture cannot be undoubtedly listed as a traditional Eastern culture in its classical sense, as according to many aspects it is on the border line of two types of cultures - eastern and western, despite the preservation of the traditional nomadic civilization. Probably a nomadic civilization had the opportunity for the adoption of elements of a foreign culture, therefore, together with the accelerated development of a sedentary civilization not only in the last century, but also in the modern era of globalization, the appearance of national culture is secretly but constantly changing, there is a process of transfer of foreign constant elements of culture even in such a special social sphere, like language. This is the evidence that "the concepts reflected in linguistic semantics make it possible to clarify the specific features of the existence of cultural constants" [Stepanov, 2001], or, according to another researcher, "a concept is a 'bunch' of ideas, knowledge, experiences, associations that accompany a word, it is like a clot of culture in the human mind" [Zhebrauskas, 2006, 20-21].

In terms of language, we take three types of concepts that came from Russian culture into the Mongolian language and culture which can characterize to a certain extent the formation process of new constant elements in the national culture at their origins.

\section{Results}

The first type is images in literature

It is clear that many images in literature contain a large semantic capacity, and because of this, they are "used as universal symbols" [Gaidin, 2009], which eventually become constant elements in national cultures. In the modern Mongolian language and culture, as in others, figurative and semantic expressions based on universal concepts of culture are often used, such as Romeo and Juliet, Don Juan, Gobsek and others. Moreover, the 20th century in the culture of Mongolia was distinguished by a translation of Russian literature, including Russian classics into the Mongolian language. And these translations, and in general the close acquaintance of Mongolian readers with Russian literature, led to the spread of a mass of expressions based on literary images in the Mongolian language. Most often they are fluid, that is to say that they appear at different times, possibly for different durations, however, some of them do not go out of use and are already idioms. 
In particular, as a result of the famous translation of "Skazki o rybke i rybake" (The Tale of the Fish and the Fisherman) by A.S. Pushkin by the Mongolian scientist/ translator T. Damdinsuren in 1938, the fairytale that is known by heart for more one generation, thus an expression of widespread consumption appeared in the speech of the Mongols "Алтан загасны эмгэн" which can be translated as "starukha iz zolotoy rybki" (the old woman from the goldfish) which means extreme greed. To state the facts, here we will cite several examples from the speeches of politicians and publicists proving the popularity of some general concepts in the modern Mongolian language, such as алтан загасны эмгэн, Данко, иүүрт and иидэт саваа.

For example, the concept of алтан загасны эмгэн in comparison with words in the Mongolian language that express the meaning of "greed" (шунал, шунахац̆, сувдаг, ховдог, хомхой) forms a more vivid expression of thought, gives speech a touch of liveliness, enhances and sharpens its emotionally expressive attributes. In the statement “Энэ бүхнээс харахад имижмейкер маань парламентын Алтан загасны эмгэний дүрийг гайгүй сайн бүтээж байгаа биз". Translation into Russian. Как видите, всё это показывает, что наш имиджмейкер неплохо создает образ парламентской старухи из золотой рыбки (As you can see, all this shows that our image maker does a good job of creating the image of a parliamentary old woman from a goldfish) [http://news.gogo.mn/r/26648, 2018.04.23]. It is the expression "the image of a parliamentary old woman from a goldfish" that creates the emotional shade of the speaker's attitude to what is being discussed. Speech expressions such as образ старухи из золотой рыљки, похожа на старуху из золотой рыбки (P.S. 1), увидишь старуху из золотой рыбки (P. S. 2), they already express a special style of speech that is present in modern Mongolian language.

\section{P.S. 1}

Алтан загасны эмгэн шуламаас ялгаагүй болсон түүнээс Ардчилсан нам сэрэмжилж чадах уу, эсвэл түүний шунал шунхагаа гүйцээх талбар болж үлдэх үY... Translation into Russian. Может ли Демократическая партия предостеречь от нее, ставшей настолько похожей на старуху из золотой рыбки, или останется площадкой для достижения своих корыстных целей... (Can the Democratic Party take measures to keep away from it whoever has become so much like an old woman from a goldfish, or will remain a platform for achieving its own selfish goals...) [http://ulsturch. $\mathrm{mn} /$ index.php? $\mathrm{view}=$ article\&type $=$ item $\& v a l=2472,2018.04 .23]$. 


\section{P.S. 2}

Энэ хүний одоогийн нөхцөл байдлыг нь харвал яг л үлгэрт гардаг алтан загасны эмгэн шиг харагдаж байх юм. Посмотришь на нынешнее состояние этого персона и точно увидишь старуху из золотой рыбки, как в той сказке (You will look at the current state of this person and you will definitely recognize an old woman from a goldfish, as in that fairytale) [http://ikon.mn/n/qaw, 2018.04.23].

The concept of "Danko" is an expression that is currently used to a greater extent in the speech of politicians and publicists. The word Danko (in the Mongolian language the original image of Danko from the story "Starukha Izergil" (Old Woman Izergil) by M. Gorky is completely preserved) usually describes those who make or can make bold steps in transforming the political and economic life of the country pursuing the wellbeing of people.

For example, “Ардчилал гэдэг гудамжинд гарч орилохын нэр биш, жинхэнэ ардчилагчид Данко шиг хүмүүс байдаг”. Translation into Russsian. Демократия - это не значит, что выйти на улицу и греметь. Настоящие демократы - это люди типа Данко (Democracy does not mean that you go out into the street and shout out. Real democrats are people like Danko) [http://www.bayangol.mn/public/news-detail.php?news$\mathrm{ID}=404,2019.01 .20]$. “Тиймээ, Монголын Данко бол У. Хүрэлсүх юм. Тэр намынхаа төлөө, монголынхоо төлөө, ард түмнийхээ төлөө цээжээ хага яран зүрхээ сугалж чадах Монгол Данко. Translation into Russian. Да, Данко Монголии есть У. Хурэлсух. Только он, как монгольский Данко, сможет раскрыть свою грудь и вырвать пылающее сердце за свою партию, за Монголию и за свой народ (Yes, Danko of Mongolia is U. Khurelsukh. Only he, like the Mongolian Danko, will be able to open his chest and rip out his flaming heart for his party, for Mongolia and for its people) [http://www.sonin.mn/news/politics-economy/11777, 2019.01.20]. These examples show how the concept of Danko is used in the speech of modern politicians. In addition, there are examples showing the use of such concepts in the spheres of fiction and journalism. For example, “Данко шиг... сэтгэл гэрэлтүүлсэн шүлгийн мөрүүд тэнгэрт татсан сүүн зам шиг харагдахад тэртээ ХХ зуунд оюутны байрны дөрвөн давхарт охидын тасгийн үүд таглаад нулимст нүдээр шүлгээ уншиж зогссон гэрэлт шар ах минь эрхгүй бодогдоно”. Translation into Russian. Увидишь, пылающие как небосвод душу поэтические строки, напоминающие Данко..., 
невольно вспоминаешь светлое дядино лицо и тот миг, когда он стоял, преградив вход девичьей комнаты на четвёртом этаже, и читал свои стихи со слезами на глазах (You will see poetic lines burning like the sky that reminds you of Danko..., you involuntarily recall the bright uncle's face and the moment when he stood blocking the entrance of the girl's room on the fourth floor and read his poems with tears in his eyes). П. Батхуяг. “Ширээ түшин бодлогошрогч” [“Pogruzivshiysya v razdum'ye, oblokotivshis' ob stol" (Lost in thought, leaning against the table) http://time.mn/n/ gzZ, 2019.01.20].

The concept “ШYYpm" (translated as "a man with a broom") is not a very widespread, but occasional-used expression which means evil creating. It appeared in the Mongolian language as a result of translations of Russian fairy tales, in which the image of Baba Yaga is present. A broom is a recognisable feature of Baba Yaga and the expression "Человек с метлой” (Маn with a broom) in modern Mongolian language is a description of those who do some evil things. For example, "Сэтгүүлч Л. Мөнхбаясгаланг олон нийтийн сүлжээнд “ШYYрm” гэх хочоор нь андахгүй. Баясаа ч өөрөө хочиндоо дуртай бөгөөд “ШYYрm” гэж дуудуулахдаа нэг их эмзэглэдэггүй”. Translation into Russian. Журналист Л. Мунхбаясгалан всем известна в социальной сети по кличке “ $и Y Y p m$ ”. Да и сама она любит свою кличку и относится к ней совершенно равнодушно [(Journalist L. Munhbayasgalan is known to everyone in the social network by his nickname "uYYpm". And she completely doesn't care about her nickname). ["People of Mongolia" magazine, 2018, No. 3, p. 26].

This image in its Mongolian understanding is also used in fiction. For example, “Чиний толгойг нохой ч тоож шиншлэхгүй. Өрөөнд чинь л архичдын шүлс цэртэй холилдоод хэвтэж байгаа биз гэж цааш үглэхийг нь муухан сонсож, "Муу шулам эмгэн, бүр шүүр унаад нисдэг эмгэнээс ч долоон дор, үхээрийн муухай эмгэн” хэмээн дотроо харааж байсан ч гадагш гаргаж хэлж чадахгүй хэвтлээ" Translation into Russian: Голову твою и собака не понюхает. Скорей, она валяется в твоем кабинете в слюнях алкашей. Далее было слышно ее невнятное ворчанье, а он лежал и про себя ругал “Подлая ведьма, тьсячу раз ть хуже той, что с метлой, дрянная старуха”, однако выговаривать эти слова не может (Even a dog won't nuzzle your head. It would rather lie in your office in the saliva of the drunk. Then its inarticulate nagging was heard, and he lay and scolded, "Vile witch, a thousand times worse than the one with a broom, 
you cheesy old woman", however cannot pronounce these words), A. Amarsaykhan "Ногоон толгой” (“Зеленая голова” — Green Head) [http://www. shuum.mn/news/newsid/9213/catid/24].

“Шидэт саваа" is a concept also widely used in the modern Mongolian language. It is a figure of speech that means a wand with supernatural power. It entered the Mongolian language as an interpretation of a Russian fairy-tale object's name - “палочка-выручалочка" (in Mongolian, “magic wand”). This concept could be found in the modern political discourse, especially when politicians find it difficult to explain the failure to fulfill their promises. For example, “Шидэт саваa байгаагүй учраaс 220 мянган өрхийг дөрвөн жилийн дотор орон сууцаар хангаж чадаагүй”. Translation into Russian. Не было такой волшебной палочки, чтобы за четыре года обеспечить жильём 220 тысяч семей (There was no such magic wand to provide housing for 220 thousand families in four years) [the newspaper "Өдрийн сонин”, 2018.05.21, No. 104].

P.S. 1

Үнэнийг хэлэхэд сэтгэл ханах зүйл ерөөсөө алга. Болдог бол иидэт саваагаар дохичихмоор л санагддаг. Честно сказать, я ничем не доволен. Была бы палочка-выручалочка, махнул бы (Honestly, I'm dissatisfied. If I had a magic wand, I would use it) [The newspaper “Засгийн газрын мэдээ”. 2015.04.15, http://www.ulaanbaatar.mn/Home/newsdetail?dataID=12265].

P.S. 2

Үнэхээр та нар тэрхүү амлалтдаа хүрэх юм бол ид шидтэн болж шидэт саваагаар хүн бүрийн ухамсар луу нэвтрэх шаардлага гарна. Тэгэхээр тэгж амласан бүхэнд иидэт саваа байдаг байх нь... В самом деле, если вы выполните свое обещание, вы просто волшебники и вам понадобится палочка-выручалочка, чтобы совладеть разумом каждого. Значит, за вашим обещанием палочка-выручалочка... (In fact, if you keep your promise, you are just wizards and you will need a magic wand to take over everyone's mind. So there's a magic wand behind your promise...) [http://niitlelch.do.am/news/t_r_zasagt_shideht_savaa_bij/2012-07-10-47, 2019.01.20].

Speaking about peculiarities of these "borrowed constants", it is appropriate to ask the question: If the constant is moving to another culture or to another language does it change its unique nature? According to Gaidin, "constants are unchangeable in natural science, but in humanities at some historical moment they may be at the center of the discourse and be un- 
changeable for a majority, and at some point they could be on its periphery, preserving their special quality while experiencing significant external modifications "[Gaidin, 2009]. We agree with this position, since the semantic content of the above-mentioned concepts sometimes changed, became a little bit more Mongolian. It happened due to the fact that their use in speech has always emphasized only their basic feature, which is their semantic function. For example, the concept "шүүрт" in Mongolian language is a symbol of an evil spirit, a terrible magical force, while "Баба Яга" in Russian culture is not always a negative character. The concept "Данко" in the Mongolian language is a symbol of courage and bravery, while in Russian literature it is primarily an image that symbolizes kindness and unselfishness. The concept of "шидэт саваа" in Mongolian means magic power that can be used at any time if desired, whereas in Russian culture, "палочка-выручалочка" comes to the rescue as a means of rescuing or as the last hope. It turns out that here we deal with the modification of literary images in the context of another national culture, and as a result, a new culture constant with a hint is formed.

In addition, despite the fact that "the destination of cultural constants is to keep society from changing", society itself, for various "other reasons tends to change, becomes a changing society" [Kuznetsova, 2017]. After all, what happened in the Mongolian language and culture in the twentieth century under the influence of Russian culture is a reflection of socio-economic, political, ideological and other changes that created a "new image" in the public consciousness, although the ideology of that time served as a strong trigger.

\subsection{The second type is proverbs}

Many proverbs in different languages are similar concerning their topics, and on this basis, various dictionaries of proverbs have been created, including Russian and Mongolian. If we will choose the closest by the meaning, we will find that in Russian and Mongolian there are proverbs that are quite similar in meaning, but expressed differently. For example, "Поспешишь - людей насмешишь = If you hurry, you'll make people laugh" (transl.note "Haste makes waste".) (Яарвал даарна. Transl.: If you hurry, you'll freeze), "Хорошее начало полдела откачало = A good start meant half the work" (transl.note "A good lather is half the shave") (Гараа сайн бол бариа сайн. Transl.: A good start ends with a good end), "Нет худа без добра = There's no bad without good" (transl.note "Every cloud has a silver lining") (Сайн юманд садаа мундахгүй. Transl.: There is no good without an obstacle) и т.д However, in the modern Mongolian language there are several proverbs of wide consumption, iden- 
tical to Russian both in components and expressiveness. It is difficult to say that all of them came to the Mongolian culture from the Russian. In order to determine their origin, special research may be required. However, in our opinion, they appeared in the Mongolian language once under the influence of the Russian language. This is evidence of the interweaving of linguistic elements in these two languages, which often occurs as a result of social, economic, and other interstate relations. And in the Russian language there are many words of Mongolian origin, such as деньга - (from “мунгэ”), алтын (from “алт”), таможня (from “тамга”), ярлык (from “зарлиг”), ямщик (from “зам+ч”), ямской (from “зам”), карандаш (from “харандаа”), есаул (from “засуул”), позже - аймак, тайга, лама, дацан, бурхан; from Kalmyk: доха (дах), малахай (малгай); from Buryat to Siberian dialects: мыдыковать (от “мэдэх") in the meaning "to think", тыкен (от “тэх") in the meaning of "lustful man" [Masgar, 2011]. Thus, such similarities remain in the language, moreover, and in culture proves the penetration of some language units or realities into others. We can see this pattern here, using examples of proverbs that probably came from the Russian language, but have already become elements of Mongolian. For example, a proverb “Долоо хэмжиж нэг огтол” is identical to a Russian one "Семь раз отмерь и один раз отрежь” (Score twice before you cut once), "Хоёр туулай хөөсөн хүн хоосон хоцордог” - “За двумя зайцами погонишься, ни одного не поймаешь” (If you run after two hares, you will catch neither), “Зуун төгрөгтэй байснаас зуун нөхөртэй байсан нь дээр" - “Не имей сто рублей, а имей сто друзей” (A friend in court is better than a penny in the purse), "Хөнжлийн хэрээр хөлөө жий” - "По одежке протягивай ножки" (Cut your coat according to the cloth) [Iderbayar, 2000].

These proverbs passed from one type of culture to another, completely different, because they have a universal value character, since they do not have a special national color. In the Mongolian language, even their grammatical (syntactic structure, tense form and mood) and logical forms are preserved, only rare words are replaced, first, where there is a culture-specific element (рубль (rouble) - төгрөг), and secondly, due to the rhythmic organization of speech, which is a feature of proverbs. For example, if in the Russian proverb "по одежке протягивай ножки" there is the rhyme "одежка - ножка", then in its Mongolian version, the words “хөнжил - хөл" rhyme, which is typical for the organization of Mongolian poetic speech. The other situation is when we compare proverbs with the same meaning, but with different national connotations. For example, the meaning of the Russian proverb 
“Рыба гниёт с головы" (Fish begin to stink at the head) can accurately express the Mongolian proverb "Тос дотроосоо өтдөг” (Oil worms from the inside), or "На безрыбье и рак рыба" (When there's no fish, a crab can be one) is close to the Mongolian "Мах ховордоход богтос түрүу" (When there is no meat, the rad is the best of the best), but the Russian expression is built on the basis of the Russian culture-specific element and Mongolian on the basis of the Mongolian one.

\subsection{The third type is metaphors}

Metaphor is a unique form of displaying reality and creating a linguistic picture of the world through the conceptualization. According to the concept of J. Lakoff, metaphors are an important mechanism of a new meaning and a life reality formation [Lakoff, 2003]. In addition, metaphors based on a borrowed vocabulary is a special phenomenon, in the sense that the same mechanism for the formation of a new derived meaning works here as in national languages, but with the use of foreign words, and they play a key role in the formation of the concept. There are two ways of forming new metaphorical concepts with the help of Russianisms. The first method is simpler and is presented by completely new metaphorical expressions for the national language created by calquing. Among the expression it is necessary to distinguish the ones with a native Russian connotation and international expressions. For example, such stable metaphorical phrases as “тархи нь эргэх "(to twist the brain) or "мухардалд орох" (dead end) appeared in the Mongolian language clearly based on Russian phrases. “Тархи нь эргэх” turned out to be a more intense and more expressive expression in the Mongolian language compared to the native Mongolian “толгой нь эргэх" (the mind boggles although they have the same meaning.

A feature of the Mongolian verb is the metaphorization of speech as a way of acquiring verb forms by foreign words. Such words can be used as an independent lexical unit, or in combination with other words, equivalent to performing metaphorical functions. For example "тооромсоглох" (to slow down - in the meaning "not to give others freedom"), "хаазлах" (add gas - in the meaning "to yell at someone"), "наастардах" (the mood in the meaning "give up") или, в сочетании с другим словом “настрийнаар унах" (literally "to bring down the mood") и т. д.

In cases where such words are combined with another verb, their original meaning seems to be implemented into the Mongolian context. Thus, in the end a completely new concept is formed. In particular, in the com- 
bination “таанц эргэх" (another version of “вальс эргэх" means to whirl in a dance in the sense of "to dance in politics") the word "a dance" creates a completely different emotionally expressive layer than the word "to dance", which has a neutral meaning... So, for example, "Оюу толгойн гэрээг байгуулсан С. Баяр, Ч. Сайханбилэг хоёрыг шоронд хийчихээд, үнийн өсөлт дээр нь та нар таани, эргэж байгаа шүу" [Өдрийн сонин. 2018.05.16.] Translation into Russian. Ясно, что С. Баяр и Ч. Сайханбилэг, достигших соглашения по Оюу толгой, посадите в тюрьму, а сами будете кружиться в танце на росте цен (It's clear that S. Bayar, CH. Saykhanbileg who reached the Oyu Tolgoi agreement will end up in jail while you will be whirling in a dance with rising prices). In this sentence the phrase " $ү н и \breve{u}$ өсөлт дээр таани, эргэх" (whirling in a dance with rising prices) creates the most vivid imaginative and emotional meaning. The same specificity can be revealed in the combination "кадр тасрах" (which can be translated as "frame break" or "freezed frame" which means "to get drunk until you lose consciousness"). This combination probably appeared as a figurative expression associated with the breakage of film tape during the demonstration of films in old cinemas. Or "цирк үзүүлэх" (to show circus meaning "to manipulate in your favor"). The combination "кадр тасрах" and some others were included in the Big Explanatory Dictionary of the Mongolian Language and examples of use can be seen even in socio-political discourses: “Архи, тамхи, секс бол хүний амьдралд байх ёстой бүх зүйл” гэж янжуур хөндлөн зуун, кадр тасрах дөхөн сууж буй Л. Эрдэнэчимэг гишүүнд сонгогчид нь төдийгүй монголын ард түмэн үнэндээ итгэл алдарч байгаа гэх. Translation into Russian: Говорят, что к члену парламента Л. Эрдэнэчимэг, не то что избиратели, даже весь народ теряет доверие, когда она сидит при срыве кадра с сигаретой во рту и говорит “водка, табак и секс - все они должны быть в жизни человека” (They say that the member of parliament L. Erdenechimeg loses people's confidence let alone her voters' when she sits in a freezed frame with a cigarette in her mouth and says "vodka, tobacco and sex - they should all be in a person's life) [http://ene.mn/index.php?newsid=13288/, 2019.02.11] Such concepts should be considered elements of the pre-existing Mongolian culture, despite the structural features.

A typical example of an idiom of international origin is the idiom “матрын нулимс унагах", widely used in the modern Mongolian language, which appeared as a result of the translation of the Russian phrase 
of German origin “Крокодиловы слёзы” (Crocodile tears), which can be found in many languages of the world. For example, “Ю. Цэдэнбал агсны мэндэлсний 100 жилийн ойг тэмдэглэхийг тэд хүсээгүй. Гэсэн атлаа одоо энэ асуудлыг тавихаар юунд матрын нулимс унагаад...байгааг ойлгохгүй байна". Translation into Russian. Они не хотели отметить 100-летие Ю. Цэдэнбала. Однако, непонятно, когда стал подниматься этот вопрос почему-то начали лить крокодиловы слёзы (They did not want to celebrate the 100th anniversary of Y. Tsedenbala. However, when this question appeared they started to have crocodile tears for some reason [http://www.sonin.mn/news/politics-economy/43417, 2019.02.13]. The word of international origin "бойкотлох" или “бойкот хийх" appeared in the Mongolian language from Russian meaning "to boycott" (after the Irish surname from the name Charles Boycott), which is also widely used in modern socio-political lexicon.

In our opinion, similar phrases in both languages in terms of content and form are very interesting which may have existed on their own before, although this happens more often in related languages. In particular, the Mongolian collocation “гэгээн цагаан өдрөөр” literally means the same as the Russian expression “среди бела дня” (in broad daylight), Mongolian “гар хумхих" - Russian “сложа руки” (with arms folded) - (гараa хумхиад суух - сидеть сложа руки), Mongolian “ханцуй шамлах” Russian “засучить рукава” (roll up your sleeves) - (ханцуй шамлаад opox - приступить к работе засучив рукава), Mongolian “нүдний цөцгий мэт” - Russian “как зеницу ока” (like the apple of one’s eye), etc.

\section{Conclusion}

So, what features are most striking when using the Russian cultural constants present in the Mongolian language and culture? Firstly, the fact that they are changeable in comparison with the ones from natural sciences, more precisely, the constants of one national culture begin to change, being present in another national culture, which may be motivated by the primary signal or the symbolic meaning of this concept, transformed into another national consciousness... Secondly, the process of appearing metaphors in speech which is taking place using foreign cultural constants or borrowed words tends to create a new shade according to the spirit of the present culture with the development of a semantic layer of this concept. Thirdly, for a number of reasons, the twentieth century for the Mongolian language and 
culture was distinguished by the implementation of more Russian cultural constants than others, and many of them are actively used in various spheres of communication, including in the social and political field.

\section{References:}

1. Y.S. Stepanov. Slovar' russkoy kul'tury [Constants. Dictionary of Russian Culture]. Akademicheskiy proyekt, Moscow (2001).

2. A. L. Zhebrauskas. Ponyatiye kul'turnykh konstant i poiski oriyentirov postsovremennosti [The concept of cultural constants and the search for landmarks of postmodernity]. Izvestiya Rossiyskogo gosudarstvennogo pedagogicheskogo universiteta imeni A. I. Gertsena. Aspirantskiye tetradi [Bulletin of the Russian State Pedagogical University named after A. I. Herzen. Postgraduate notebooks], Saint Petersburg, № 3 (20) (2006), pp. 20-21.

3. B. N. Gaidin. Vechnyye obrazy kak konstanta kul'tury [Eternal images as a constant of culture]. Phd Thesis, Moscow (2009). http://www.dissercat.com/ content/ (Accessed 20 January 2019)

4. T.F. Kuznetsova. Kul'turnyye konstanty i ekologiya kul'tur [Cultural constants and cultural ecology]. Magazine/portal "Kul'turnyye konstanty i ekologiya kul'tur", № 4 (2017).

5. T. Magsar. Kommunikatsiya kul'tur i sledy vliyaniya russkogo yazyka na mongol'skiy [Communication of cultures and traces of the influence of the Russian language on Mongolian]. Proceedings of the XII MAPRYAL Congress, Shanghai (2011).

6. B. Iderbayar. Slovar' upotrebitel'nykh angliyskikh, russkikh i mongol'skikh poslovits [Dictionary of common English, Russian and Mongolian proverbs]. UB (2000).

7. G. Lakoff, M. Johnson. Metaphors we live by. The University of Chicago Press, Chicago (2003), pp. 195-196. 